\title{
審美的補綴のための久損部歯槽堤増大形成
}

$\begin{array}{llllllllll}\text { 葛 } & \text { 山 } & \text { 賢 } & \text { 司* } & \text { 鎌 } & \text { 田 } & \text { 透* } & \text { 元 村 洋 一* 荒 木 久 生* } \\ \text { 申 } & \text { 基 } & \text { 䓀* } & \text { 宮 } & \text { 田 } & \text { 隆* } & & & & \end{array}$

\section{Partoially Edentulous Ridge Augmentation for Aesthetic Restoration: A 3-Cases Report}

\author{
Kenji Katsurayama* Tohru Kamata* Yohichi Motomura* Hisao Araki* \\ Kitetsu Shin* and Takashi Miyata*
}

Localized abnormalities in the morphology of the alveolar ridge may arise from a cleft palate, advanced periodontal disease, trauma, and extractions associated with excessive force. As a result, the height and bucco-lingual width of the lost alveolar ridge may cause problems with establishment of the ideal relationship of the alveolar ridge and bridge pontic. Furthermore, loss of a portion of the alveolar ridge in the maxillary anterior region may cause problems not only with estetics, but also with hygiene and pronounciation. Therefore, various implansts and surgical graft procedures have been devised for such cases to restore the localized defect in the alveolar ridge to a more natural morphology.

Cohen described an alveolar ridge augmentation procedure for a localized defect that made use of hydroxyapatite (HA). The method using subepithelial connective tissue graft reported by Langer and Calagna, and Garber and Rosenberg is very effective in correcting class I alveolar ridge defects. Abrams and Schart reported the rolling technique and the pedicle connective tissue graft that removed the epithelium.

This report discusses the surgery and postoperative course for three cases where alveolar rigde augmentation surgery was performed in a defect, the morphological abnormality in the alveolar ridge was restored, and the final prosthesis was compleated. HA was used in the first case to restore the alveolar ridge, a subepithelial connective tissue graft was employed for the second, and the rolling technique was used in the third case.

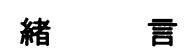

部分的な歯槽堤の形態異常は, 口蓋裂や進行し
た歯周疾患, 外傷, および暴力的な抜歯処置など によって生じる.その結果, 喪失した歯槽堤の高 さ, 唇舌的幅は, ブリッジのポンティックと歯槽 堤の理想的な関係の確立を妨げる。さらに，上顎 前歯部においては，衰失した歯槽堤が，審美性だ けではなく発音機能や清掃性などの障害へとつな

* 明海大学歯学部歯科臨床研究所 


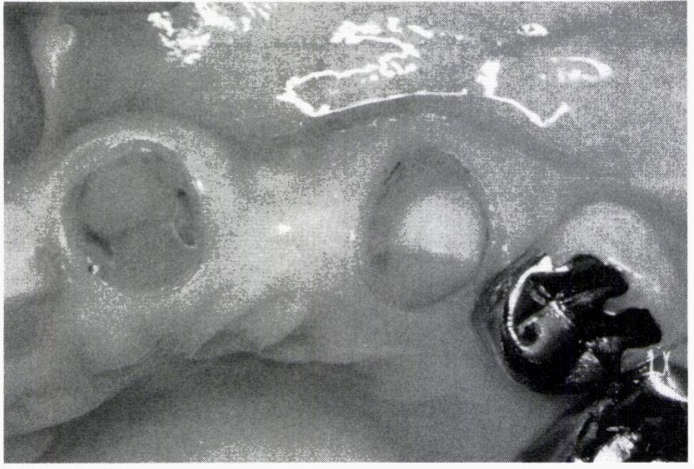

Fig. 1 Occlusal view of 6 months healing extract maxillary left lateral incisor.

がる，そこで，このような症例に対して，部分的 に欠損部歯槽堤をより自然な形態に回復するため に種々のインプラントや外科的な移植術が考案さ れてきた. Cohen"1) は, ハイドロキシアパタイト （HA）を用いた部分欠損の歯槽堤増大術について 述べている. Langer と Calagna ${ }^{2,3)}$, Garber と Rosenberg $^{4)}$ らにより報告された上皮下結合組織 移植を用いた方法は, Class I 歯槽堤欠損を修正 するために大いに役立った. $\mathrm{Abrams}^{5)}$ と $\mathrm{Schart}^{6)}$ らは, 上皮を除去した有茎結合組織弁移植やロー ルテクニックを報告した。本論文では，症例 1 に おいて HA を用いた歯槽堤の保存, そして症例 2 では, 上皮下結合組織移植, 症例 3 では, ロール テクニックを用いて欠損部歯槽堤増大形成術を行 い歯槽堤の形態異常を修正し, 最終補綴に至った 以下の 3 症例について, 術式と経過を追って報告 する.

\section{症例}

\section{症例 1}

抜歯直後の HA の移植による歯槽堤の保存.

患 者：38 歳, 女性.

初 診: 平成 1 年 10 月 24 日.

主 訴：上顎左側中切歯の疼痛.

既往歴：特記事項なし.

現 症：6力月前に左上中切歯に外傷を受け, そのまま放置. 最近になり, 唇側歯肉部に膿瘍が 形成され，自発痛を認める.

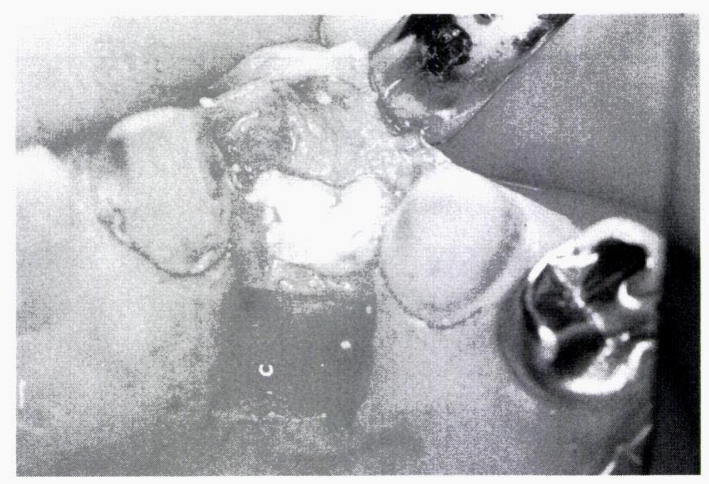

Fig. 2 An autogenous connective tissue removal from the palate was grafted between labial flap and residual alveolar ridge.

術 式：上顎左側中切歯の抜歯後, 抜歯窩内の 肉芽組織を十分搔爬し，口蓋側に切歯乳頭部を基 底部とした有茥歯肉弁を部分層で形成する。この 歯肉弁は，移植後の血液供給を良好にするため, 先端から基底部にかけて歯肉弁の幅が大きくなる ようにする，次に抜歯窩内にハイドロキシアパタ イト（HA）骨補填材を歯槽骨頂部まで緊密に移 植し，移植材の安定と漏出を防ぐため，ゼラチン 製局所止血剤である山内社製スポンゼルを膜状に 圧接した後, 抜歯窩の形態に合わせトリミングし, 移植した骨補填材の上から力バーをする。次に形 成しておいた有茎歯肉弁を抜歯窩中央に移動させ 周囲歯肉と縫合する。

症例 2

上皮下結合組織移植による歯槽堤増大形成術。

患 者：25 歳, 女性.

初診: 平成 2 年 5 月 20 日.

主 訴：上顎左側側切歯の動摇が気になる。

既往歴：特記事項なし。

現 症：上顎左側側切歯には，形態，咬合関係 ともに不適合なレジン前装冠が装着されていた。

術 式：上顎左側側切歯抜歯後 6 力月, 唇舌的 な歯槽堤の欠損が認められる (Fig. 1)。欠損部口 蓋側に 2 本の垂直切開と水平切開からなる長方形 切開線を入れ，口蓋側から唇側に向かって長方形 の部分層弁を剝離翻転させる。この垂直切開の長 さは, 移植材料の量によって決定される. 骨膜と 


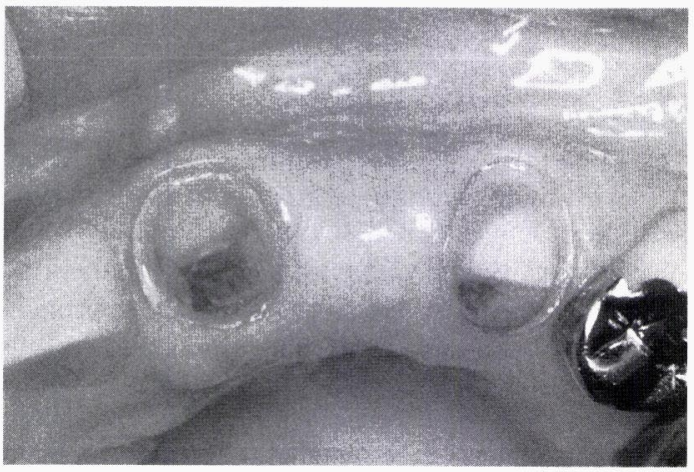

Fig. 3 The view of 1 year postsurgical healing. Note reconstruction of labial ridge contour.

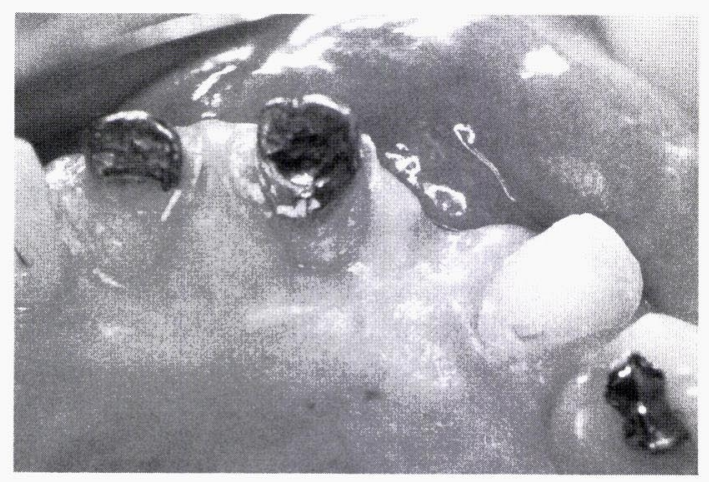

Fig. 4 Presurgical view of a partially edentulous ridge defect in the area of maxillary left lateral incisor.

結合組織は，自家結合組織移植材の血液供給源と なるため歯槽堤上に残しておく，長方形の歯肉弁 を剥離した口蓋側の下部結合組織を移植に必要な 大きさに採取し，部分層の長方形の歯肉弁と歯槽 堤陥凹部の骨膜と結合組織との間に移植する (Fig. 2). 創面は, 閉鎖創となるため, 術後の疼痛 は認められない. 術後 1 年, 術前と比較して上顎 左側側切歯欠損部歯槽堤の陥凹は, 改善した (Fig. 3).

\section{症例 3}

有茎結合組織弁移植によるロールテクニックを 用いた歯槽堤増大形成術.

患 者：30 歳, 女性.

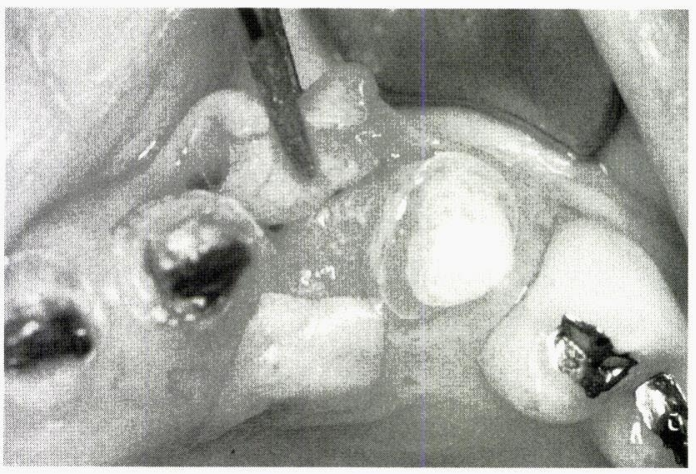

Fig. 5 The subepithelial connective tissue pedicle graft was tucked into the pauch.

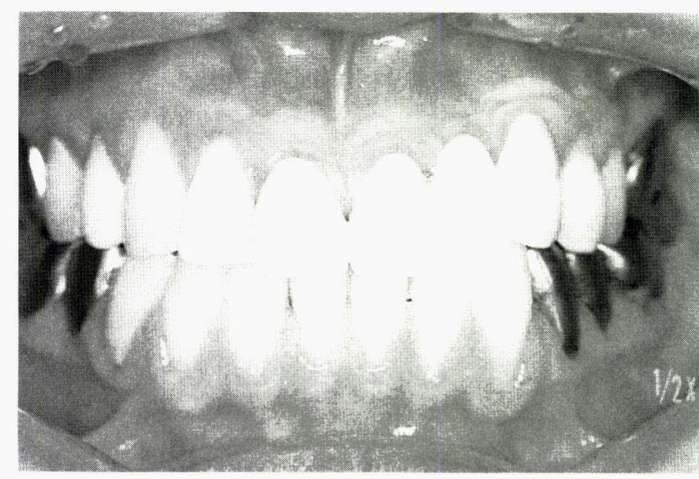

Fig. 61 year postsurgically, final fixed prosthesis in placed.

初 診: 平成 4 年 3 月 17 日.

主 訴: 上䪽左側側切歯の補綴.

既往歴：特記事項なし.

現 症: 上鿓左側側切歯は, 2 年前外傷により 抜歯, 現在にいたるまで部分床義歯を装着してい た.

術 式：上顎左側側切歯欠損部歯槽堤は, 唇舌 的な幅の喪失による陥凹が認められる (Fig. 4). 歯槽頂の水平切開を起始点として, 口蓋側に向っ て, 厚さ $1.5 \mathrm{~mm}$ の上皮と結合組織とからなる長 方形の上皮結合組織有茎弁を部分層で形成する. 長方形の歯肉弁下部の口蓋から，最大限の上皮下 結合組織有茎弁を剥離する. 次に唇側の粘膜と歯 槽骨との間に, 移植片の受容体となる袋状のス ペースを形成しておく，その中に結合組織有茎弁 をロール状にして詰め込むようにして移植する 
(Fig. 5)，長方形の上皮結合組織有茎弁を元に戻 して閉鎖創として，水平マットレス縫合で縫合す る. 右上中切歯から左側犬歯までの固定性ブリッ ジ装着後 1 年の状態を示す (Fig. 6). 上靧左側側 切歯ポンティックの高さは, 隣接歯と調和してい る. 審美性, 機能性, 清掃性は良好で, 患者の満 足も得られている。

\section{考察}

審美性を考慮した固定性ブリッジの補綴前処置 として, 部分欠損部における歯槽堤増大形成術を 行った 3 症例を報告した. 症例 1 の HA の移植に よる歯槽堤保存は, 抜歯直後に歯槽堤の保存を行 うことにより歯槽堤のダメージを減らすのに有効 であるが，たいていは，後に歯槽堤増大形成術が 必要になってしまう。したがって, 後にインプラ ント埋入の可能性を考えると, 今後は人工材料の 移植よりも GBR 法7,8)などの骨誘導再生法が適応 と思われる，症例 2,3 では，上皮下の結合組織 を採取したので，術後は供給側が閉鎖創となり， また創面を 1 箇所にすることができた。この方法 を用いることにより歯槽堤の増大量は多少劣る が, 違和感や術後の疼痛を最小限にすることがで きた。

\section{結 論}

固定性ブリッジの補綴を考慮した補綴前処置と して久損部蕷堤の歯槽堤増大形成術には，審美性 の高い補綴物を作製するために非常に有効である ことがわかった．今後は，インプラントによる補 経を考慮した歯槽堤増大形成術が必要になると思
われる。

\section{参考文献}

1) Cohen, H. V. : Localized ridge augmentation with hydroxyapatite : Report of case. J. Am. Dent. Assoc. 54 : 108, 1983.

2) Langer, B. and Calagna, L. J. : The Subepithelial connective tissue graft. A new approach to the enhancement of anterior cosmetics. Int. J. Perio. Rest. Dent. 3:23-34, 1982.

3) Langer, B. and Calagna, L. J. : The Subepithelial connective tissue graft. J. Prosthet. Dent. 44:363-367, 1980.

4) Garber, D. A. and Rosenberg, E. S.: The edentulous ridge in fixed prosthodontics. Compend. Cont. Ed. Gem. Dent. 2 : 212-224, 1981.

5) Abrams. L.: Augmentation of the deformed residual edentulous ridge for fixed prosthesis. Compend. Cont. Ed. Gen. Dent. 1 : 205-214, 1980.

6) Schart, D. R. and Tarnow, D. P. : Modified roll technique for localized alveolar ridge augmentation. Int. J. Perio. Rest. Dent. 12 : 415-425, 1992.

7) Buser, D., Dula, K., Hirt, H. P. and Berthold, $\mathrm{H}$. : Localized ridge augmentation using guided bone regeneration, Buser, D., Dahlin, C. and Schenk, R. K., Guided bone regeneration in implant dentistry, Quintessence Publishing Co. Inc., St Louis, 1994, 198-233.

8) Bahat, O., Fontanesi, R. V. and Preston, J. : Reconstruction of the hard and soft tissue for optimal placement of osseointegrated implants. Int. J. Perio. Rest. Dent. 13:71-83, 1993.

別刷請求先：申 基苦

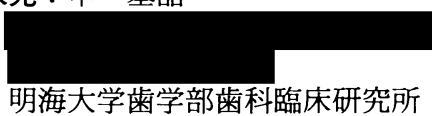

